\title{
Independencia y su expresión léxica en la Aurora de Chile*
}

\author{
Mariano Franco Figueroa ${ }^{* *}$ \\ Universidad de Cádiz, España
}

\begin{abstract}
Resumen
Tomando como base documental el semanario Aurora de Chile, se realiza un análisis lingüístico que describe las caracterizaciones léxicas acomodadas a los nuevos contextos sociolingüísticos en esta época histórica de la independencia colonial y los fenómenos gramaticales que permiten observar rasgos diferenciadores en la lengua que se asienta en esta sociedad chilena. Por una parte, resulta interesante constatar la variación léxica que este texto periodístico, portavoz de una ideología ilustrada, proporciona para alcanzar un mejor conocimiento del grado de penetración del nuevo léxico político-social, con voces en muchos casos recreadas con las acepciones dominantes en las comunidades insurgentes. Por otra, la descripción de los fenómenos gramaticales y del léxico general de este corpus aporta datos concretos acerca de la preferencia de estas variantes lingüísticas y del grado de estandarización que van adquiriendo, como usos emergentes de la lengua española en Chile, bien como asentamientos de estructuras sintácticas y de léxico
\end{abstract}

* Del proyecto FFI2008-02718/FILO, Ministerio de Ciencia e Innovación.

** Para correspondencia, dirigirse a: Mariano Franco Figueroa (mariano.franco@uca. es), Departamento de Filología, Facultad de Filosofía y Letras, Universidad de Cádiz, Avda. Gómez Ulla s/n, 11003, Cádiz, España. 
tradicionales o bien como mecanismos innovadores en la gramática $\mathrm{y}$ en el vocabulario diferencial americano.

Palabras clave: léxico iluminista, léxico hispanoamericano, español de Chile.

\title{
INDEPENDENCE AND ITS LEXICAL EXPRESSION IN THE AURORA DE CHILE
}

\begin{abstract}
Based on the weekly newspaper Aurora de Chile, a linguistic analysis is here introduced including both the description of lexical characterizations as they adapted to the new sociolinguistic contexts in the historical period of the colonial emancipation and the grammatical phenomena that allow for the observation of differentiating features of the language being established in the Chilean society of the time. On the one hand, it is of interest to observe the lexical variation displayed in this journalistic text, which represents an illustrated ideology, in order to better understand the degree of penetration of the new political and social vocabulary, with voices in many cases recreated with uses dominating the insurgent communities. On the other hand, the description of the grammatical phenomena and general vocabulary of this corpus provides concrete data regarding the preference of these linguistic variants and the degree of standardization that they acquire in time, as emerging uses of the Spanish language in Chile, either as the consolidation of traditional syntactic structures and vocabulary or as innovative mechanisms in the differential American grammar and vocabulary.
\end{abstract}

Key words: lexicon of the Enlightenment, lexicon of Latin American Spanish, Chilean Spanish.

Recibido: 30/03/10. Aceptado: 25/04/10.

\section{INTRODUCCIÓN}

Los acontecimientos sociohistóricos de las colonias hispanoamericanas a comienzos del s. XIX, caracterizados por la pujanza en los procesos de emancipación política y su ideario insurgente, provocan la asunción de 
proyectos legislativos y constitucionales que culminan en la independencia como nación y exigen, asimismo, el esfuerzo de sus dirigentes políticos por divulgar el compromiso adquirido en pos de la libertad de su pueblo a través de decretos, panfletos, pasquines, periódicos, etc. No sorprende, entonces, que la prensa aparezca ligada al objetivo propagandístico ideológico en la afirmación del sentimiento de liberación y de independencia de las colonias americanas y que muestre en su contenido informativo no solo los cambios políticos y sociales, sino también el consiguiente reflejo lingüístico, con la creación de un vocabulario que se recrea en formas y significados adecuados al nuevo perfil ideológico de la sociedad americana que, aun coincidiendo en las inquietudes liberales manifiestas en la carta magna gaditana, contravenía la utopía doceañista en la conformación de una única nación de ciudadanos españoles de todos los dominios de las Españas, europeos y de ultramar.

La difusión de esta nueva mentalidad, fruto del ocaso de las sociedades coloniales y del surgimiento de las primeras comunidades insurgentes, a través de gacetas y de periódicos, conlleva el cambio inevitable en el uso de un lenguaje, ahora iluminista y liberal, y la conformación de una lengua identificadora de su origen americano. De esta caracterización y de su importancia para el estudio de la lengua hablaba Guitarte (1980) al postular una periodización del español americano, con insistencia en el análisis de estos recursos periodísticos como fuentes útiles para el estudio de las actitudes lingüísticas y de los cambios que conllevan para la lengua. En el caso del español chileno, esta época de transición hacia la independencia está marcada por un proceso de estandarización ya visible en la estabilización de la lengua escrita de los medios de comunicación de masas, que exhiben una sociedad en la que, como comentaba Matus et al. (1992: 562), la emergente aristocracia criolla "toma conciencia del valor de lo autónomo, desarrolla sentimientos de amor a la patria y logra definir una identidad propia. Nuevas ideas comienzan a ser difundidas en el Catecismo político-cristiano, escrito por José Amor de la Patria, y en los periódicos de la época, en especial la Aurora de Chile".

En este contexto se sitúa la primera labor periodística chilena, la que se atribuye a la publicación del semanario Aurora de Chile ${ }^{1}$, y que hemos tomado como base para el análisis lingüístico que nos describa los fenómenos

Este primer periódico nacional editó un prospecto y 62 textos, distribuidos entre el 13 de febrero de 1812 y el 1 de abril de 1813, con 58 números, dos ejemplares extraordinarios y dos suplementos. Resulta interesante el dato que Manuel del Villar (1982), en la introducción a "Aurora de Chile. Primera Edición Facsimilar", ofrece con la existencia de tres prospectos que se publicaron en fechas diferentes. Tomamos como texto básico la transcripción en PDF, y 
gramaticales diferenciadores y las caracterizaciones léxicas acomodadas a los nuevos contextos sociolingüísticos. Por una parte, nos interesa la variación sociolingüística que el texto periodístico nos proporciona y que nos permite un mejor conocimiento del vocabulario y del grado de penetración del nuevo léxico político-social. Por otra, la peculiaridad geográfica, junto a las diferencias de estilos y de niveles sociolingüísticos, nos muestra el uso contrastivo como variables propias de un diasistema que las aglutina y las explica históricamente como opciones intrínsecas en la lengua.

Con respecto al primer objetivo del análisis, cabe destacar que el marco histórico propicia que este periódico chileno genere un léxico específico, ideológico e, incluso, contrastivo con el vocabulario político peninsular, como corpus documental básico en el que determinar los usos lingüísticos que caracterizan a los diferentes grupos sociales y, aun como pequeña contribución lexicográfica, la identificación de esta parcela de la lengua chilena en la época de su independencia.

Por lo que atañe a la descripción de los fenómenos gramaticales y léxicos generales de este corpus periodístico, resulta provechoso, en este periodo de la historia de América, constatar la preferencia de estas variantes lingüísticas y el grado de estandarización que van adquiriendo como usos emergentes de la lengua española en Chile, bien como asentamientos de estructuras sintácticas y de léxico tradicionales o bien como mecanismos innovadores en la gramática y en el vocabulario diferencial americano.

\section{AURORA DE CHILE: PORTAVOZ POLÍTICO}

Ya en su cabecera, la Aurora de Chile se postula como periódico "ministerial y político", vocero de esta prensa insurgente que transcribía los principios del liberalismo e insistía en la instrucción del ciudadano como medio para alcanzar la plena soberanía popular, aunque su adscripción partidista se apartara en muchos aspectos de la consigna ideológica prevista, como lo corrobora la defensa continuada de su director, Camilo Henríquez González, de la libertad de prensa ante actos de posible censura ${ }^{2}$.

citamos los ejemplos por el número del ejemplar, con la letra $a$ para los del año 1813, seguido de la página, aunque contrastamos las grafías con el documento facsímil.

2 Esta es la postura que adopta cuando no incluye un decreto que, como órgano ministerial y político, debía dar cabida, y publica un extracto del discurso del poeta inglés Milton sobre 
En su prólogo justifica, ante el cambio de mentalidad que se está produciendo, como "consecuencia necesaria de un systema Colonial y opresor", la aparición del periódico, "En medio de tantos bienes [...] y dulses esperanzas se hechaba menos un Periodico, que las anunciase, y difundiese, que generalisase las ideas liberales" (Pr., 3). Se concibe como un medio que procura expandir el beneficioso espíritu ilustrado entre la población: "Oh, ¡si la Aurora de Chile pudiese contribuir de algun modo á la ilustración de mis Compatriotas!” $(1,6)$. La posición política crea un léxico nuevo o con nuevas acepciones propias del ambiente ideológico liberal e independentista, como patria, que no se traduce por el lugar en el que se nace sino que se complementa por el conjunto de "los hombres reunidos baxo un gobierno y unas leyes que á todos favorecen igualmente" $(37,4)$, o patriota, "Yo entiendo por patriota un hombre ilustrado y virtuoso" (37, 6). Se defiende un gobierno republicano, con una "regla general: para que un Estado sea estable, es necesario que se divida su Autoridad legislativa: y para que goce de tranquilidad, es necesario que el Poder executivo se reuna y concentre" $(5 \mathrm{a}, 5)$. Entiende del poder económico de la sociedad chilena cuando admite que si los Estados Unidos son graneros para las "islas de Barlovento y Sotavento", en cereales y arroz, "Chile lo es de Lima y de sus costas" $(13,8)$.

El laicismo que rebosa en los ideales revolucionarios franceses no tiene cabida en la constitución gaditana ni en las americanas, identificadas por su carácter confesional (García Godoy 1998: 53). Así, en este periódico chileno se plasma un "homenage a la Religion de nuestros padres", porque "Jamás esta hija luminosa de los cielos aprobó el despotismo, ni bendixo las cadenas de las servidumbres, si no es que tomemos los abusos por principios, Jamás se declaro contra la libertad y dignidad de las naciones" $(10,3)$. Añade, además, la lengua a la base constitucional de los americanos, "unidos por las relaciones de idioma, y religion" $(7,5)$. La urbanidad y la buena educación son temas que preocupan y de las que se hace eco el periódico, con noticias sobre Lima, como ejemplo de cultura $(4,5)$, y de Buenos Aires, ciudad privilegiada por su fondo editorial en lo que toca a la enseñanza de idiomas, "algunos jovenes, que desean aprehender el Ingles, pero no encuentran diccionarios, ni gramaticas Inglesas, que se dice haber en Buenos-Ayres" $(6,4)$. No obstante, se reivindica la lengua española como vehículo de trasmisión de las enseñanzas que el pueblo precisa, porque "El

la libertad de prensa, al que preceden unas esclarecedoras palabras: "Ya que estáis diciendo que volvamos a ser esclavos, a lo menos aprovechémonos del corto tiempo que nos resta para despedirnos de la libertad" $(36,2)$. 
primer error es enseñar las ciencias en una lengua apartada del uso comun y trato de las gentes" y "conviene hacer ver el influxo que tienen las lenguas vulgares en los progresos de las ciencias y de la ilustración" (3a, 6).

\section{LOS CONCEPTOS IDEOLÓGICOS Y SU EXPRESIÓN LÉXICA}

La confrontación de sectores sociales que radicalizan sus posiciones ideológicas provoca un cambio en el lenguaje que hace patente la propia historia social de la comunidad hablante. La divulgación de este vocabulario en las publicaciones periodísticas de la época, con voces que asumen ahora nuevos contenidos fuertemente politizados, se recrea también en obras satíricas y burlescas que pretenden aleccionar y salvaguardar al pueblo de este recién nacido lenguaje revolucionario ${ }^{3}$.

La iniciativa lexicográfica se hace sitio en la polémica social y política y basta comprobar algunos de los artículos con sus definiciones que los diccionarios recogen con clara intención propagandística. Así, el Nuevo Vocabulario Filosófico-Democrático indispensable para todos los que deseen entender la nueva lengua revolucionaria, publicado en Sevilla en 1813, expresa el enfrentamiento político e ideológico de la sociedad y la distinta interpretación que el léxico manejado contiene: "se fue introduciendo un lenguage dulce, que mansamente iba lisonjeando las pasiones mas vivas, y despertando el orgullo y el deseo de independencia é insubordinacion", "El charlatan filósofo tuvo infinitos secuaces, discípulos y defensores; y trastornadas las cabezas; comenzó todo el mundo á gritar pacto social, libertad, igualdad, derechos, sin saber ni entender lo que significan estos vocablos" (I, pág. 7). Esta obra refuerza el rechazo social de un sistema político que, como se ha expresado arriba, abominara de sus creencias religiosas: "las gacetas democráticas (ya se sabe) no son otra cosa que un libelo inflamatorio diario" (II, pág. 17), que es "trompeta del ateismo, de la

Estas obras dan buena cuenta del enfrentamiento político de los partidarios y detractores, como es el caso de los bandos gaditanos, que cuentan, por el lado de los serviles o conservadores, con el Diccionario razonado manual para inteligencia de ciertos escritores que por equivocación han nacido en España (1811), anónimo, y con el Diccionario críticoburlesco del que se titula Diccionario razonado manual para inteligencia de ciertos escritores que por equivocación han nacido en España, de Bartolomé José Gallardo (1811), como respuesta por parte de los liberales. 
rebelion, de la impudencia y del libertinage" (II, pág. 20). A la defensa de la libertad de prensa que defiende la Aurora de Chile, "tiempo mas favorable á la libertad de prensa" $(30,3)$, "confia, que en todas las Américas lleve la vanguardia de la libertad" $(10,1-2)$, podemos confrontar la opinión que recalca el $V F D$ sobre la función social y política del periodismo: "su libertad de prensa, no ha hecho mas que poner el mundo al reves" (II, pág.17).

Pero ningún otro documento de la época como el periódico nos va a proporcionar información y datos sobre la actualidad del estado de opinión de la sociedad a través del vocabulario que utiliza. A esta actividad editorial con pretendida finalidad política se acoge nuestro objeto de análisis, la Aurora de Chile, como base y centro de una prensa de temática variada, pero de innegable posición política liberal y, por tanto, insurgente en sus proclamas del derecho a la independencia de Chile y a la conformación de su propio gobierno constituyente: “¿Hay cosa mas escandalosa, y mas aproposito para abrirnos los ojos que el espiritu que han manifestado las cortes de Cadiz contra las Americas" $(35,2)$, "iinmensas regiones han de depender de una pequeña comarca de la Europa?” $(29,7)$. No se confía en los partidarios del Antiguo Régimen y se duda de sus planes políticos, porque son "arbitristas de tres siglos" (Ex. 1, 4), con el sentido despectivo que va calando en esta voz desde finales del s. XVII ${ }^{4}$ como "persona que propone planes disparatados para aliviar la hacienda pública', porque sostienen un "un Gobierno puramente aristocràtico, qual es el actual de Cádiz" $(25,8)$. $\mathrm{Su}$ ansia independentista queda justificada en el olvido de la abrumadora supremacía social, "há sido mas aflictivo á la America, que unos territorios tanto mas estensos, y una poblacion incomparablemente mas numerosa estubiese sujeta, y dependiente de un rincon peninsular del continente Europeo" $(7,4)$.

El espigueo del léxico político en nuestro periódico permite, asimismo, describir la ideologización de los términos empleados, muchos de ellos con las acepciones acuñadas fuera de de nuestra lengua e incorporados como neologismos de filiación francesa o inglesa, como consecuencia de su funcionalidad en sus respectivos sistemas políticos. De la diversificación del vocabulario político, podemos destacar los campos léxicos, con palabras clave y sus derivados, y con términos semánticamente asociados, referidos

\footnotetext{
4 Véase la sustitución de esta voz por el término proyectista en la política ilustrada, como comenta Álvarez de Miranda (1985).
} 
todos a la parcela de terminología ilustrada o iluminista, la que trata de los derechos del hombre y la más general sobre la noción política ${ }^{5}$.

En lo que concierne a los conceptos propios del movimiento ilustrado, se destaca la palabra clave $l u z$, como símbolo de la actividad cultural, "siglo de las luces" $(27,4)$, "la difusion de las luces" $(13,3)$, "progresos de las luces" $(3,5)$, y cuya carencia supone un menoscabo en la mejora social, "Tenemos pocas luces" $(4,4)$, "escaséz de luces, no permitiràn hacer algo de provecho" $(2,3)$; sus asociaciones léxicas nos llevan a su antónimo, "Las generaciones despues de haber vegetado en la obscuridad" $(29,2)$, y a su derivación etimológica ilustrar, ilustración e ilustrado, con acepciones más políticas que culturales, "instrumento de la ilustración" (Pr., 1), "gobierno ilustrado y benefico" $(32,7)$. Otro término clave lo representa la razón, asociada muchas veces a luz, ilustración y libertad, "baxo los auspicios de la razon" $(12,8)$, "razón y libertad" $(16,6)$.

La felicidad es otra de las voces que durante el siglo XVIII añade a su contenido más moral y religioso las acepciones de bienestar y de prosperidad económica y social, tanto en el individuo como en la comunidad. Este es el sentido trascendente de "levantar el templo de nuestra felicidad" $(5,8)$, y el deseo ilustrado de caminar hacia su consecución comunitaria, "hacia la felicidad" (Pr., 1), "la felicidad pública" $(13,3)$, "su "felicidad personàl depende de la felicidad pública" $(2,4)$. La asociación se establece con los sentimientos de seguridad y de libertad, "seguridad, libertad, y felicidad" $(7,6)$, y con su adjetivo feliz, siempre en torno a la comunidad social más amplia, "hacer felices à las naciones" $(13,3)$. Fuera de la protección de esta nueva situación política, se pierde la libertad y la seguridad, se encuentra inevitablemente con su antónimo, "infelices esclabos" (Pr., 2). La felicidad, como situación de bienestar social, supone una asociación con los términos beneficencia, prosperidad, progreso y utilidad pública, que, como en el caso de progreso 'Encaminamiento [...] hacia una suma mayor de ilustracion, de libertades y de goces', y de prosperidad 'estado feliz', asumen presupuestos ilustrados en el diccionario de Marty Caballero, "sentimientos de beneficiencia, y las ideas de equidad" $(12,1)$, "prosperidad pública" $(6$,

La acotación del campo léxico político-ideológico y social se presenta a través de unidades léxicas clave que se definen y delimitan en el conjunto a través de relaciones formales, es decir, de derivados, y de asociaciones semánticas que el contexto descubre. Del atractivo de este tipo de vocabulario ilustrado ya se hacía eco Rafael Lapesa (1966-1967) y ha tenido continuación en investigaciones lexicográficas generales (Álvarez de Miranda 1985, 1992, 2004) y de referencias más concretas, como los dedicados al contexto hispanoamericano (Hildebrandt 1961; Gardella 1969; Vallejos Llobet 1987; García Godoy 1998, etc.). 
3), a pesar de que el $V F D$ discrepe de su sentido más positivo, "p. e.felicidad de los pueblos, significa estrema ruina y miseria" (I, pág. 10).

Otro pilar del pensamiento ilustrado lo representa la defensa de los derechos del hombre ("declaración de derechos" 16,6 ), y su campo léxico y nocional, tan denostado por el $V F D$ : “¿Cual [literato] el que como verdolaga en huerta no nos haya esplayado en ellas los derechos del hombre, la libertad, la igualdad, la soberanía, la ilustración y toda la demás sarta de tonterías?" (I, 44). Los derechos humanos se asientan en sentimientos de fraternidad (6, 4 ), de espíritu filantrópico $(2,4)$, entendidos en el vocabulario revolucionario con mayor contenido laicista como 'buenos sentimientos hacia el prójimo' (García Godoy 1998: 109). Su sinónimo en el contexto ilustrado americano es la humanidad 'caridad y amor a todos los hombres', "amigos de la humanidad" $(13,2)$, siempre presente, como afirma el VFD, en "los libros filosóficos ó proclamas republicanas", "Pero la verdad es que entre los democráticos no tienen ella mas lugar que en los libros, porque existe una "contradicción entre los dichos y los hechos de los republicanos" (I, 95).

La libertad como un derecho inalienable del hombre, "la libertad, en sentir de Aristóteles" (23, 6), entendida como "Dios de la Libertad $(22,2)$, y adornada con la expresión sinestésica dulce, "La voz dulce de la libertad" $(28,6)$. Suele aparecer acompañada del adjetivo civil, "libertad civil" (8, $3)$, en relación con los eslóganes revolucionarios franceses y acordes con la expresión rusoniana de "pacto social" $(38,4)$, "libertad civil, fraternidad y union" (Ext. 4), "promesas de libertad, igualdad, y fraternidad $(7,4)$, y aclamada como emblema de la idiosincrasia chilena, "O la libertad, ò la muerte es el lema chileno" (Ext. 2, 3). Su adjetivo libre se asocia con otros términos propios de esta noción semántica, "estados libres, soberanos é independientes" $(7,6)$, "independencia é igualdad" $(10,5)$, "augusta soberania" $(7,5)$, "todos los hombres en el órden de la naturaleza son iguales" $(2,6)$, voces cargadas de significado ilustrado del nuevo régimen como recalca, con cierto desprestigio, el VFD: "[...] parece que la única esplicacion que tenga algun respeto con todos los dialectos republicanos es la de definir la libertad de este modo: trampa de bellacos para coger tontos" (I, 21), "igualdad es el pandero republicano" (I, pág. 22). Las voces derivadas liberal y liberalidad se acogen a la renovación semántica del cambio político como "partidario de las nuevas ideas revolucionarias', "gaceta liberal" $(17,2)$, como califica un colaborador que desea que se inserte una carta en este periódico, "Liberalidad de sus principios" $(28,3)$. Las palabras libertinaje, liberticida y libertador se cargan igualmente de connotaciones políticas y son empleadas por los opositores al cambio como denuncia de la libertad que ejercen los republicanos o por los revolucionarios si ayudan a desembarazarse de la opresión y del despotismo realista, "apellidan seguridad a la tirania, propiedad al despotismo, y libertad 
al libertinage" $(8,2)$, "con el placer que vieron los Liberticidas nuestras diferencias" (Ext. 2, 2), "libertadores de la Patria" $(32,5)$.

La sociedad también renueva el contenido significativo de su campo léxico, con la inclusión de todos los miembros de la comunidad en una estructura civil filantrópica, en la que destaca el término amistad como sinónimo de fraternidad y solidaridad social, "Sociedad economica de Amigos del pais" $(23,2)$. Así, lo público es sinónimo de 'servicios sociales que incumben a todos', que Terreros significa como propio de una sociedad civil, de una sociedad de ciudadanos, ("espiritu público", "bien público" 2 , 4; "la causa publica" 17, 3; "perfeccionar la razon publica" 40,4) y de ahí la necesidad de publicista 'individuos que defiendan el derecho público', "formar un publicista" $(18,5)$, término recogido en Marty Caballero. El neologismo civilización, asentado en el francés y en el inglés, pero también en el español en el siglo XVIII, alude al 'alto grado de desarrollo de una comunidad', aunque con referencia a la América española, esta voz encierra además contenidos culturales de mayor ámbito social, con implicaciones en modas, costumbres e, incluso, la lengua de sus individuos (García Godoy 1998: 101-102). Marty Caballero lo pone en relación con todo el bagaje léxico ilustrado, "Cultura, ilustracion, progreso de las luces, desenvolvimiento de las doctrinas, máximas, nociones ó ideas moralizadoras" y añade el sintagma civilización "moral: la reunion de leyes, creencias, costumbres y virtudes de un pueblo".

El sentido negativo de civil como grosero, ordinario, vulgar' no aparece en el uso actual, como hemos visto en la expresión "libertad civil" $(8,3 ; 30$, 4), sino que se impregna de los aires ilustrados que acompañan a civilización, a cívico y a civilidad ("ayre de civilidad" 9,6). Los que pertenecen a esta sociedad son ciudadanos, en la acepción que Marty Caballero recoge, "toda persona que goza de derechos civiles garantidos por las leyes, miembro de una sociedad ó nacion libre é independiente", que gozan de los derechos de la ciudadanía, que comparten los derechos de su misma patria, "compañeros ciudadanos" (6, 3), "ciudadanos de Chile" (Pr., 3), como revela la formación derivada conciudadanos $(25,6)$, "hermanos y conciudadanos" $(7,5)$. Para los nuevos americanos, familia aglutina a todos los nacidos en el nuevo continente, "gran familia" $(7,5)$, "Indios, y Españoles, formen una sola familia" $(12,8)$, siempre con la distinción de criollo, como identificador de su nacionalidad, y europeo ${ }^{6}$, según el lugar de nacimiento, "Españoles

\footnotetext{
6 Resulta curioso que se aluda a gallego con cierto sentido despectivo, aunque no está claro el significado metonímico de 'español', en el contexto "habia siempre oido decir que los
} 
Americanos y nosotros" $(10,5)$, de ahí su lucha para evitar "que el nombre de criollo se confunda con el de un esclavo" $(27,2)$. Contrario al término ciudadano se muestra la voz vasallo, que representa al individuo sin sus derechos fundamentales y en situación de vasallaje, "vasallage", "vasallos, perpetua servidumbre" (Pr., 2).

La noción de soberanía recae en la voz patria, con sus derivados y sus asociaciones nocionales, que representan, asimismo, un cambio semántico producido por la mentalidad ilustrada. Se percibe la patria con un nuevo sentimiento de extensión estatal y de identidad nacional en la que los individuos alcanzan sus plenos derechos y con la que se contrae el deber de su defensa y de su contribución para la prosperidad del bien común. De ahí las acuñaciones ilustradas de patriota y patriótico, "entiendo por Patriota un nombre ilustrado" $(37,6)$, "firmeza patriotica" $(6,5)$, "zelo patriótico" (Pr., 2 ), y de otros derivados, "compatriotas, y hermanos" (Pr., 2), "expatriacion" $(13,4)$, esta última recogida en el CORDE, en una descripción de Guayaquil (Ecuador), en 1774, pero que en la Península se documentará años más tarde, ya en el inicio del s. XIX. La propia voz patriota, unida siempre al nuevo ideario, "liberales, y patriotas" (Pr., 1), desata oposiciones léxicas asociadas a determinada posición política, como muestra la expresión "patriotas y sarracenos" (6a, 4), a la que el VFD asigna un claro valor despectivo: "quinta esencia de la impiedad, de la ratería y la desvergüenza" (I, 30) y crea su antónimo "partido anti-patriota" $(38,6 ; 7 \mathrm{a}, 2)$. Relacionados con patria aparecen nación, reino o pueblo, como palabras que destacan su diferencia geográfica y referencian la independencia e idiosincrasia de un territorio en la amplia comunidad americana, "nacion soberana" $(6,2)$, "reino de Chile" (2, 5), "pueblo de Chile" $(44,7)$. Sinónimos de nación en este contexto liberal serán la expresión cuerpo político, "las naciones son cuerpos políticos" $(2,4)$ y con menor uso (García Godoy 1998: 146 y 302) estado $(2,4)$. La voz pueblo asume, igualmente, las ideas ilustradas, "En la democracia, el soberano es el pueblo" $(16,4)$, como constata la crítica caracterización del $V F D$, "pueblo quiere decir hez y la zupia de una nacion" (I, pág. 28). Sus derivaciones manifiestan igualmente la posibilidad de acuñar acepciones despectivas en referencias partidistas, "populacho afeminado" $(41,4)$, "un pueblo de muchachos ó mugercillas" $(9,5)$. Incluso la deserción de un pueblo acarrea el mecanismo de derivación despreciativo: "el pueblo de Pasto", "infame pueblo Pastuso" $(41,4)$.

Gallegos eran cobardes [...] haré alistar en mis batallones no á Gallegos, sino á los valerosos Jaonas" (7a, 1). 
El campo léxico de la política se carga de adjetivos que designan las fórmulas y las estructuras elegidas para el gobierno, con sus apreciaciones partidistas que añaden palabras connotadas ideológicamente. La política como 'arte de gobernar' ofrecía también una interpretación malévola, como recoge Terreros cuando afirma "Algunos han distraido la voz política á significar el arte de engañar". El uso de político como sustantivo se afianza a principios del s. XIX como sinónimo de "persona relacionada con asuntos públicos' (García Godoy 1998: 120).

El término policía, aunque comparte con política la necesidad del buen gobierno y de la urbanidad, se especializa en la vigilancia de las cosas que, sin estar comprendidas en las leyes, afectan a la buena educación de los ciudadanos (García Godoy 1998: 123). Ante la propuestas de destrucción del sistema patriótico, se debe crear una "opinión pública" una "sociedad de la opinión" $(25,7)$ que evite las deserciones en el pueblo, y de esto ha de encargarse "la vigilancia de la alta policia" $(25,7)$. La posición confrontada trae una larga lista de términos definidores de su ideologia. Así, se nos presentan "patriotas y sarracenos" (6a, 4), aunque la voz sarraceno se había cargado desde la Edad Media de connotaciones negativas referentes a los 'enemigos de la cristiandad o herejes', en el s. XIX se emplea en América para designar a los realistas, como sinónimos de gachupines, maturrangos o chapetones, con claro sentido político peyorativo para los defensores del cambio de régimen y su vinculación a la independencia colonial. El desprecio de los liberales americanos por los que sostienen el régimen de adhesión a la metrópolis se deduce de muchos de sus apelativos, "leprosos, que nos han venido de España, á quienes unos llaman Saracenos, algunos los Empecinados, y otros los Embreados" $(27,5)$. Se produce la "Guerra politicoliteraria, entre liberales y serviles" $(17,5 ; 24,5)$, y mientras los liberales llevan en su bandera "Libertad de la patria" $(17,5)$, los serviles "persecucion y despotismo" (17, 5). El bando liberal denuncia la actitud "machiabelica" $(17,3)$ de algunos y los desprecia, "infame multitud Maquiabelistas" (5, $8)$, porque son "déspotas" $(15,3)$ y tienen como rasgos identificadores la "arbitrariedad, y despotismo" (Pr., 2). Los que no rechazan y combaten la situación del "systema Colonial y opresor" (Pr., 3) son llamados "goticos siervos" $(17,5)$. Las oposiciones léxicas son continuas, "Republicanos y realistas, entre Americanos y godos, entre oprimidos y opresores" (45, 3), con una nota al pie de página en la que se refiere que godo es "voz usada en México a los enemigos de la libertad, subversores del gobierno" (42, $3)$. El empleo de la palabra insurgente se señala con un comentario del editor al margen con el siguiente texto: "tal era el execrable lenguaje de los opresores de la libertad del genero humano: á su vista son insurgentes y rebeldes los pueblos generosos, que convaten por sus derechos" $(9$, 
3). Sus partidarios son tildados de "saracenos, revolucionarios" $(20,2)$, "sospechoso de francesismo" $(17,6)$, proclives a "insurgir" (9a 1) y a la "insurreccion y jacobinismo" $(6,4)$. Para estos revolucionarios, sus enemigos se presentan como "conjurados" $(10,9)$, "fatuos panigeristas" $(18,4)$, "faccionistas arrojados" $(21,5)$, "intrigantes ${ }^{7}$, usurpadores, y despotas" $(17$, $3)$ y "subversores del orden" $(25,7)$, que andan "de gavilla" "en cuadrilla, en junta' $(44,5)$, voz que el CORDE documenta desde 1604-1618, a la que Terreros añade que se aplica a "la chusma, personas despreciables" y que Marty Caballero recoge el sentido 'cuadrilla de gente, por lo general malhechora'; son personas que persiguen alterar el cambio político que se persigue consolidar mediante un "complot" $(10,8)$, neologismo francés del que tenemos constancia de uso en el siglo XIX, aunque el CORDE ya señala una documentación en 1612, en la historia sobre las provincias del Río de la Plata, de Ruy Díaz de Guzmán, y en Tomás de Iriarte, en 1788. Incluso, rechazan el espíritu moderado de las nuevas instituciones ante las traiciones de los tradicionalistas, como lo confirma la necesidad de ser más radicales en la defensa de sus convicciones, "funesto moderantismo" (4a, 1), "ya se borrò del diccionario político de Chile la funesta voz moderantismo" (4a, $1 ; 12 \mathrm{a}, 7)$.

También podemos documentar las estructuras políticas que van asentándose en la América independentista. Así, tenemos muchos de estos términos con sus derivados que se definen en el nuevo orden político: el sentido galicista de asamblea, y los anglosajones de cámara, con su sinónimo de procedencia política francesa convención, y de congreso, serán sinónimos del más gaditano cortes, "asamblea general de todos los ciudadanos" (16, 4), "Camara, y Convencion" $(12,8)$, "Congreso" $(7,3)$, "de Cádiz, en las Isla de León, sus Cortes" $(7,5)$; la constitución se establece como marco de ley suprema que preserva los derechos del hombre, "la constitucion es tan liberal, equitativa y hospitalaria" $(29,2)$, aunque el $V F D$ ya advierte de su dudosa inmutabilidad: "á una constitucion democrática siempre la sigue la misma desventura que al puerco, que en un año nace, engorda, y es llevado al matadero" (I, 33-34). Las palabras federado ("Provincias federadas" 7, 3), federal (Palacio Federal de Caracas, 7, 6), federalista (todos somos Federalistas" 40, 3), federativo ("Principos federativos y republicanos" 40, 3), confederación ("comunidades de su confederacion" 6, 6), confederar, revitalizan su uso político relevante con significados análogos a la estructura

7 El sentido peyorativo de este término, que no se recoge en el diccionario académico hasta 1817, estaba ya en el lenguaje de las Cortes de Cádiz (García Godoy 1998: 119), a partir de la voz intriga 'malas artes empleadas en la política'. 
de los Estados Unidos, con claro sentido liberal de 'unir y aliar los pueblos para un fin común' (Marty Caballero) y no con cierto significado peyorativo por su acepción 'disgregación', de ahí que, cuando se rompe con las cadenas de la opresión metropolitana, América "toda ella se confedera" $(40,7)$, "confederadas Provincias de Venezuela, 7, 6). El poder ejecutivo recaía en el gobierno, pero acompañado del adjetivo benéfico o regenerador (aunque tiene documentación en mitad del s. XVI y en el s. XVIII, su uso con sentido político se aprecia al principios del s. XIX, según datos del CORDE), más acordes con los ideales reformistas ilustrados y no tanto revolucionarios, "Gobierno benéfico" $(5,8)$, "Gobierno benéfico [...], regenerador" (Pr., 2), "Govierno equitatibo, sabio, y humano" (Pr., 3), o democrático, "gobierno democrático" $(16,4)$, que amortigua el significado negativo que el término democracia ("de la democracia à la monarquia" 16,4) asumía en el español de principio del s. XIX (García Godoy, 1998: 254), y que el VFD confirma: "Que por activa significa ateo, ladrón, asesino colocado en mando y gobierno" (I, pág. 27). Al legislativo lo representan "Legislador, y Directores" $(2,1)$, sinónimos en este periódico, como representantes del poder legislativo en cualquier sistema político, y relacionado la última voz con Directorio (Pr., 3), de evidente influencia francesa, y los representantes elegidos ${ }^{8}$ delegado, diputado $(11,8)$, senador $(16,6)$. Se crean otras estructuras particulares como la "primera Magistratura" (Pr., 3; 16, 5), con la acepción que, s. v. majistrado, Terreros apunta: 'personas que tienen el cuidado de la policía, ó gobierno de la Ciudad, ó República', aunque también se documenta la institución judicial ("una magistratura, que expida en nombre del pueblo los negocios ordinarios" 16, 5), y el "Instituto Nacional $(12,8)$, también dedicado a la difusión de las enseñanzas ${ }^{9}$ y regidores específicos cabildante $(8,7)$, americanismo general en Sudamérica, según la Academia. La palabra junta reclama ahora, a principios del s. XIX, el significado de 'institución ejecutiva de carácter extraordinario' (García Godoy 1998: 241), junto con su derivado juntista, ausente en las obras lexicográficas, "Junta que con título de Gubernativa fue creada" (10,5), "Juntistas" (21, 2). Las representaciones locales tienen su expresión en la "Municipalidad" (Pr., $3)$, que el CORDE documenta en 1825 , con amplia aceptación americana,

8 Aunque aparece el término tribunado (10,3), palabra galicista que se usaba para designar un cuerpo del poder legislativo antes de Napoleón, no parece que aquí se esté empleando con sentido político sino como 'orador de ideas populares' (Marty Caballero).

9 En este caso, se critica la falta de atención a la población juvenil araucana, "Parece que la educación de la juventud Araucana ha de tener mejor suceso en esta capital" y se afirma "El INSTITUTO NACIONAL hallarán unas proporciones, quales no pueden tener en otra escuela del Reyno" $(12,8)$. 
la "provincia" (7, 6), el "Cabildo ilustrado y filantrópico" $(41,5)$, las "Corporaciones y funcionarios" $(43,6)$, el "vecindario de la Concepcion" $(28,2)$, etc. Hay referencias continuas al sistema monárquico español y a la "Regencia de Cádiz" $(10,5)$ como sistemas opuestos al de la república que se defiende como el más adecuado (16); con voces que manifiestan igualmente actividades propias de los nuevos sistemas de gobierno parlamentarios: "derecho de las elecciones" $(40,4)$, "vuestros sufragios" $(40,4)$, "electivo" (8a, 4; 9a, 5), "electos" (6a, 1), etc.

\section{EL LÉXICO COMÚN. CRIOLLIZACIÓN E INDIGENISMOS}

Centrados en el aspecto lingüístico, la adopción de unos usos frente a otros confirma la variación lingüística de este periódico que incluye, además de la finalidad tipológica textual, el estilo personal de su redactor, con su español aclimatado a esta nación americana. Se observa tanto la presencia de una norma más tradicional, acorde, en este caso, con el discurso escrito, como el incremento del vocabulario con términos nuevos o recreado ${ }^{10}$ para este contexto histórico. A pesar del registro lingüístico que impone el medio periodístico, no faltan ejemplos de un estilo popular, "los espectadores voluntarios, que se apellidan mirones" $(12,10)$, "repantigarse" (2a, 9), con expresiones más coloquiales, "no nos quite el pan de la boca" $(40,4)$, "iguales juegos de manos" (6a, 4), y determinados significados metonímicos, convertidos luego en tópico sociológico, "los Quixotes, que no conocen los peligros que nos rodean con el enemigo, y la alianza, solo tratan de establecer leyes" $(31,5)$.

La tendencia conservadora escrituraria ${ }^{11}$ se muestra en muchos términos, algunos de ellos cultismos, como abastecedor (1a, 2), aleve (8a, 4), avalorar

10 Véase la reflexión que propone Álvarez de Miranda (2004) para entender el fenómeno de la poligénesis temporal de términos, con referencia al incremento del vocabulario que se percibe en el Siglo de las Luces.

11 A este patrón pueden adscribirse formas poco frecuentes como $\operatorname{Sud}(9,1-3)$, América del Sud $(10,5 ; 12,5 ; 22,2)$, Carolina-Sud $(12,4)$, voces como aprehender $(4,2)$, comprehender $(1,4 ; 2,4)$, contraher $(18,4)$, desprehender $(28,5)$, emprehender $(3,6 ; 8,5 ; 30,4)$, sorprehender $(4,3)$,o la forma arcaica previde $(33,4)$, algunas con formaciones analógicas y no siempre recogidas lexicográficamente, aunque Terreros sí cita, por ejemplo, a la última, y la del adjetivo grande sin apocopar, "la grande estencion" $(2,3)$, "esta grande obra" $(3,5 ; 5,10)$. Idénticas variantes más antiguas se confirman con el uso del femenino frente, "à la frente 
(35, 3), bajá 'mandón' (41, 4), bolsillo 'bolsa para el dinero' $(38,2)$, concusión 'exacción arbitraria de un funcionario' $(19,5 ; 26,6)$, condigno $(7 \mathrm{a}, 2)$, convictorio $(8 \mathrm{a}, 8)$, referido a la educación en colegios jesuitas; cuarto 'vivienda' $(18,10)$, contraventor $(43,8)$, contristar (Ex. 1, 9), raro para el $D C E C H$, corchete 'ministro de justicia' $(8,5)$, delustrado $(27,3)$, denunciación $(7,1)$, dignación $(4,1)$, disconvenir $(21,6)$, entitativo (11a, $7)$, estafermo 'muñeco' $(38,4)$, feraz 'fértil' $(16,3)$, fomes 'causa' $(14,2)$, habitud (2a, 4), que Frago recoge en el Correo del Orinoco (2007: 165), hospital 'hospitalario' (Pr., 3), también en el Correo del Orinoco (Frago 2007: 165), iniciatorio $(10,4)$, inmarcesible 'inmarchitable' $(37,6)$, intitulado (17, $2 ; 17,5)$, mayoridad, minoridad (40, 3-4), ministrar (3a, 5), noticiar $(20,3)$, oblar, oblacion $(27,6)$, oliva de la paz 'olivo' $(5 \mathrm{a}, 1)$, ocurrir $(13,1)$, parla $(6 \mathrm{a}, 7)$, perdimiento $(26,5)$, perorar $(35,2)$, el $D C E C H$, documenta en 1685 , pobrez $(23,2)$, pulgada $(16,2)$, pusilanimidad $(26,7 ; 27,3)$, raciocinar $(15$, $3)$, el CORDE lo documenta en Fray Bartolomé de las Casas (1527-1550), recogida (Ex. 1, 6), antigua para Marty Caballero, por 'acogida' o 'asilada', remoción $(17,3)$, renitencia $(22,6)$, renitente $(11,9)$, retardación $(4,1)$, retrete 'cuarto pequeño' $(4,6)$, la Academia lo cita como 'letrina' en 1832 $(D C E C H)$, sobrestante 'capataz' $(12,6)$, teliz 'manta para cubierta de las caballerías' $(41,7)$, testa 'cabeza, entendimiento' $(21,4)$, transportación (4a, $3)$. No obstante, también hay muestras de un léxico que inicia su asentamiento en esta época, como muestra la cronología que ofrece el CORDE: autómata $(18,5)$, desde 1791, aunque ya en Terreros, capotón 'levita' $(8 \mathrm{a}, 8)$, en 1761 , conferenciar $(6 \mathrm{a}, 7)$, finales del s. XVIII (DCECH), diccionaristas $(17,5)$, en 1802, hombrearse $(27,6)$, en 1838, infaltable $(39,2)$, en 1903, infatuado $(10,8)$, en mitad del s. XVIII, metodizar $(39,5)$, segunda mitad del s. XIX, patentizar $(18,4)$, en 1782, con documento argentino, pañolería 'indumentaria de paños' $(2,7)$, en 1854 , probidad $(18,3)$, desde el s. XVIII, propender $(27,6)$, en 1783 , sereno $(8,6)$, el DCECH lo documenta en el s. XIX y el $D R A E$ lo estima actual en Perú como 'vigilante municipal de la seguridad nocturna', cigarrero $(1 \mathrm{a}, 6)$, desde 1838 , transitante $(11,3)$, sin referencias lexicográficas y documentales.

Este aspecto neologista se constata en el vocabulario técnicocientífico que la Aurora de Chile, en su afán por difundir los aspectos más novedosos para la población chilena, recoge como portavoz también de las transformaciones sociales, económicas y científicas: ácido carbónico (4,

del quinto cuerpo" $(9,1 ; 9,4,10,7 ; 18,3)$, "á la frente de los negocios" $(23,1)$, o de las expresiones de la fecha: "Santiago y Febrero 27 de 1812" (Ex. 1, 1), "Santiago Febrero 28, de 1812" (Ex. 1, 2). 
6), de documentación tardía para la Academia, que no lo cita hasta la mitad del s. XIX, como también lo recoge Marty Caballero, aeriforme $(4,4)$, el CORDE da cita en 1881 , átomo $(12,1)$, bismuto, cobalto $(14,4)$, gas $(4,6$; 18, 7), la Academia en 1817 (DCECH), deleteria $(4,6)$, Academia en 1843 $(D C E C H)$, aunque el CORDE en 1591 , eudiómetro $(4,7)$, recogido por Marty Caballero, el doblete farmacia y botica (3a, 5), fosforado $(4,7)$, fósil $(14,4)$, la Academia en 1817 (DCECH), hydrógeno $(4,7)$, la Academia en 1843 (DCECH), laboratorio químico, mercurial (6a, 6), molécula $(4,6)$, Terreros, piróforo (4a, 6$)$, Marty Caballero habla de esta preparación química inflamable, sulfurado $(4,7)$, zinc $(14,4)$, etc.

Junto con esta perspectiva diacrónica del léxico empleado en este texto periodístico, las variedades diastráticas muestran las diferentes parcelas que evocan. Algunas de ellas son de relevancia histórica reconocida, como la de la jerga marinera en suelo americano, y otras de justificación discursiva por el propio tema abordado. Así, las finanzas y las relaciones comerciales imponen el uso de su lenguaje específico: amonedación $(26,4)$, amonedar (2a, 5), balancear, bloqueo $(17,7)$, galicismo referido aquí a privación de la libertad de comercio, cargo, data $(26,5)$, compensar $(16,8)$, contrabalancear $(16,7 ; 26,8)$, el DCECH documenta al principio del s. XIX, decremento (16, $8)$, desfalcar $(16,8)$, ecónomo $(11,7)$, en México es 'gerente', empréstito $(14,8)$, erario público $(12,4)$, con redundancia léxica de uso muy popular, jactura 'quiebra' $(28,6)$, manufactura $(5,6)$, moneda (2a, 5), monopolista $(40,6)$, el CORDE documenta en 1803, en Filipinas, numerario 'dinero en moneda acuñada o efectivo' $(16,8)$, pecho 'tributo' $(43,3)$, peculio $(15,8)$, peso fuerte 'moneda de plata de veinte reales' $(31,5)$, que registra Marty Caballero, aunque ya Terreros registraba su sinónimo peso duro, principal $(14,8)$, reembolsar, $(14,8)$, seña 'moneda de madera' $(2 \mathrm{a}, 5)$, que Frago (2007: 165) recuerda su prohibición en el bando bolivariano publicada en Caracas en el año 1821. En el campo de la medicina, además del indigenismo chucho (1a, 6), se recogen términos como gálico 'mal venéreo', galicada $(41,2)$, lúe venérea 'infección de sífilis' $(5 \mathrm{a}, 6)$, miasma $(4,5)$, raquitis $(3$, 8), CORDE en 1780, aparece en Terreros y en la Academia en 1817, según el $D C E C H$, trismo 'cerramiento convulsivo de las mandíbulas' $(3,8)$, aún falta en la Academia en 1832, según $D C E C H$, aparece en Marty Caballero, virulento (1a, 3), la familia léxica de vacuna $(3,5 ; 11,6)$, vacunado, vacunación $(11,6)$, vacunador $(11,7)$, vacunal $(14,2)$, vacunatorio $(18,10$; $24,1)$, ya en la Academia en 1817 , vómito negro $(3,8)$, que recoge Terreros y que Marty Caballero concreta como "especie de calentura biliosa endémica de la América, y que padecen comunmente los europeos que van á aquellos paises", cólera celeste (4a, 6), Marty Caballero registra cólera azul, como "tercer periodo del cólero-morbo, caracterizado por el coloración violada de 
la piel y particularmente de la cara, el hundimiento de los ojos, las manchas de color azul que aparecen en la superficie del cuerpo".

Diferentes actividades y oficios reflejan el vocabulario de la minería, con aportes específicos como masa 'porción de metal derretido' $(17,1)$, que recoge Marty Caballero, piña 'porción de mineral de plata' $(26,4)$, placer 'veta militar' $(17,1)$, que Frago (1999: 156) considera extendido en lugares de América a partir del sentido más marinero como 'terreno limpio para la siembra', estaca 'cata de minas' $(17,1)$; o en expresiones empleadas en la guerra y la milicia como a bayoneta calada $(2,5)$, pasar a cuchillo $(2,5)$, fondo de masita 'dinero que se aparta para el pago de los soldados' $(20,1)$, munición de boca $(31,5)$, artillería volante $(10,7)$, y en muchas de las palabras que recogen los acontecimientos bélicos del momento como atrincheramiento $(6,6)$, bombardera $(3 \mathrm{a}, 2)$, anticuado en su acción 'artillero', colectar (Ex. 1, 6; 5, 7, 9, 2), significado militar que recoge el CORDE en 1772, comandar $(5,7)$, galicismo militar tardío, para el $D C E C H$, conscripción 'servicio militar' (Ex. 1,7), que la Academia sitúa en Argentina, Bolivia y Ecuador, convoyar (Ex. 1, 7; 6, 1), galicismo bélico usado ya en el s. XVII, coracero $(9,4)$, fajina, gavión 'cestón de tierra que sirve de parapeto' $(9,2)$, garita $(44,5)$, mortero $(20,2)$, paisanaje $(39,2)$, aquí en contraposición a militar, en el léxico de los liberales tuvo también el sentido peyorativo de 'trato de favor a los paisanos, nacido de una especial pasión nacional', requisición 'embargo para el servicio militar' $(11,9)$, vivandero 'proveedor para el abastecimiento de un ejército' $(11,9)$, hoy en Andalucía 'persona que lleva el hato a un poblado', según la Academia, etc.

La jerga marinera deja constancia de su uso popular con terminología propia y con adaptaciones de algunos de sus términos a realidades terrestres. A la terminología náutica responden anclar $(1 \mathrm{a}, 7)$, beque $(46,6)$, buque 'cabida' $(32,2)$, calafate $(3 a, 2)$, carenar $(8,4)$, desaguadero $(20,2)$, picar 'cortar la arboladura' (1a, 7), sirte ("estrellado contra unos sirtes cerca de la isla" 1a, 7), etc., o la expresión patente de corso (10a, 5); se suman los marinerismos americanos arribar y su derivado arribo ("Pasar á Jamaica baxo pretexto de arrivar de Martinica [...] descubrir sus disposiciones para una revolucion" 11, 1; "Habiendo arrivado", "desde mi arrivo", una persona" 17, 2, 22, 1), banda ("Banda Oriental" 40, 1; "exercito de la otra vanda" 1a, 6), o el más localista que se deduce del contexto "[vientos del nordeste] conocidos de los marineros con el nombre de Papagallos" $(33,3)$.

En lo que toca a la variedad diatópica, cabe señalar, en principio, el uso preferente que se muestra en algunos términos: agarrar por coger, "se empiezan à agarrar todos los dias aquellas hojas" $(16,1)$; almácigo por almáciga como 'lugar de siembra', "Para sembrar el tabaco [...] se hará el almacigo" $(16,1,2)$; barranca por barranco, "regueros de sangre, que se 
ven en las barrancas" $(8 \mathrm{a}, 5)$, término general en la zona rioplatense, en sus acepciones 'ribazo o mole de tierra en un arroyo o quebrada' y 'orilla alta y llana de los ríos', aunque para el $E A$ se trata de un uso preferente; bravo por valiente, "manos brabas" $(5,8)$, "braba tropa" $(10,7)$; temblor por terremoto "temblores" (1a, 4, 4a, 6), totalmente generalizado; trincar "coger por sorpresa" "para trincarlos con todas las cargas" $(41,4)$; cuadra por manzana de casas, "estas tres quadras" $(31,6)$, "tres mansanas principales de aquel barrio" (31, 6), el CORDE documenta también en 1811-1813 esta acepción; ramo por rama "arbol [...] que estienda sus ramos" $(5,8)$. Entre estos términos destacan algunos que responden al concepto de americanismos léxicos históricos, por su origen y vigencia indiscutiblemente colonial: encomienda (3, 5), "antiguos mandones" (1a, 5), "mulatos ó castas" (35, 2), donde aparece casta en sentido de ascendencia africana diferente del concepto de grupo étnico de las sociedades indias (Alvar 1987: 23 y ss.), reducción (6a, 7), "suertes de estancia" $(36,5)$, etc.

De inequívoca influencia dialectal se muestran los meridionalismos hacienda ("haciendas, que estan en el campo" $(10,10)$, hacendado $(12,2)$, traste "trasto" "trastes que no pudieron transportar" $(39,2)$, el canarismo ingenio $(11,3)$, o las voces de ascendencia norteña ferreria $(17,1)$ y fierro (6a, 6), como comenta Frago (2007: 165), que justifican la fama de esta región en la producción del metal, "hierro de Viscaya" $(14,9)$. Los americanismos léxicos tienen su confirmación textual en los términos abaleado 'baleado', abismarse 'sorprenderse', acequia 'arroyo', aporratar 'abastecer, monopolizar', aprontar 'preparar', bodegón 'tienda de comestibles', covacha 'aposento rústico cubierto', desparramar 'divulgar una noticia', embarrilar 'meter en barriles las hojas del tabaco', garantir 'garantizar', de raigambre galicista, mazo 'porción de tabaco atado', mezquinar 'escatimar', moreno 'negro', ocurrir 'acudir', palote 'rodillo para apretar el tabaco', pardo 'mulato', plata 'dinero', quebrada 'paso entre montañas', ramada 'cobertizo, tienda', refaccionar 'acondicionar o arreglar edificios', socavón 'galería inclinada en la mina', tacho 'cubo, vasija para lavar', transar 'ceder, transigir', tronada 'huracán', zambo 'hijo de negro e india y al contrario'"12.

12 "abaleado y colgado" (Suplemento, 1, 1), derivado que no recoge la Academia; "lo abismaba en una melancolia profunda" $(11,2)$, “desgracias en que lo abismaron" $(29,2)$; “estàn aprontando à hacer viage” $(41,4)$; “calles y asequias” $(41,1)$, ‘albañal' y 'arroyo' en Perú, México, Argentina, Chile, Bolivia y Colombia; "se les aporraten las Mulas” $(40,6)$, para Neves (1975) es chilenismo con el sentido de 'abastar', aunque es de mayor extensión el significado 'monopolizar'; "apronten su quota de tropa” (43, 5), Morínigo (1985) lo refiere a Argentina, Paraguay y Uruguay, da entrada también a apronte 'preparativos', 'carrera destinada a entrenar caballos', en el Río de la Plata, para el EA es rural 'preparar el caballo 
A innovación americana chilena responde el uso de chimba 'en las ciudades con río, el barrio que queda en la banda más pobre', "La Chimba es una selva á donde no ha entrado aun la policia" $(41,2)$.

A pesar de que el periódico editorializa sobre la sociedad indígena chilena y valora el carácter de los indios araucanos como símbolo de la resistencia histórica ante el dominio europeo, "solo el duro Araucano rehusa las cadenas" $(23,7)$, la terminología indoamericana solo está presente en los referentes que gozan de un amplio conocimiento y extensión social, y, por razón de la acotación geográfica, en la lengua más general de la zona andina, la quechua, junto con algunas voces aprendidas de lenguas del primer contacto, taína y caribe, y del imperio azteca, la nahuatl. Así, la palabra mapuche maloca se usa en toda la América Meridional, "guerras intestinas de los Indios, que llaman malocas" $(3,5)$. Los términos de la zona caribeña, como los taínos barbacoa $(16,2)$, aquí referido como una "forma de catre" que se usa en el secado del tabaco, canoa $(33,4)$, huracán $(33,3)$, sabana $(31,6)$, los antillanos y caribes mangle (Ex. 1, 7), tiburón $(37,6)$, y el uso de términos aborígenes de zonas diferentes, como realidad familiar, como ocurre con caribe "salvaje', "danzando alrededor como caribes" $(17,5)$, o con el término cacique $(12,7 ; 6 \mathrm{a}, 4)$, responden también al concepto de panamericanismo. Idéntica divulgación universal caracteriza a los nahuatlismos cacao $(33,4)$,

para el viaje', y en Autoridades es "voz modernamente usada"; "bodegones, ò tiendas de abastos" (2a, 5); "construirse en las salas de aquella el numero posible de cobachas" (Ex. 1, 6), 'lugar cubierto rústico', 'aposento rústico', término de amplio uso en Andalucía y América; "desparramarlos sediciosamente" (4, 3), que la Academia sitúa en el uso de México, Argentina, Paraguay y Puerto Rico; "se separan las hojas, se embarrilan" $(16,2)$; "se obliga à garantir y conservar la seguridad" $(1,4)$, poco frecuente en el español actual, pero con uso completo y no defectivo en Argentina y Uruguay, según la Academia ( $D P D)$; "para hacer los mazos, se hierben unos palos del mismo tabaco" $(16,1)$; "no mesquinará su existencia" $(5,8)$, de uso general en América, desde Argentina hasta Colombia, según el $D C E C H$; "ocurra al llamado de su alcalde" $(8,6)$, arcaísmo de uso general para Morínigo (1985); "voluntarios, y pardos" $(15,8 ; 17,4)$, "100 hombres de pardos y morenos" $(36,5)$, mulato en América, procedente de un cruce con raza negra, Alvar (1987: 170 y 183) comenta su paralelismo con moreno, eufemismo para negro muy arraigado en América; "palo redondo, que llaman palote" (16, 2), 'sirve para apretar las hojas del tabaco', en Argentina y Uruguay significa 'rodillo', según el $D R A E$; "donde hay plata para eso" $(41,2)$, "plata macuquina" $(2 \mathrm{a}, 5)$; "por la quebrada que se dirigia al campo" $(29,2)$, con otras acepciones regionales como "bancales en las laderas de los montes', hoy en la zona andina, 'dique, presa', en Argentina y Chile; "en algunas partes almasenes, y en otras ramadas" $(16,2)$; "refaccionar y hacer en las murallas cualquier compostura" (Ex. 1, 6), que el CORDE documenta desde la mitad del s. XVIII; "socabon en las minas" (14, 3), ya en fray Reginaldo de Lizárraga y en la crónica de indio Guamán Poma de Ayala (Frago 1999: 57; Franco Figueroa 2007: 482); "un brasero de cobre, un tacho" (8a, $8)$, “destrayen y transen" $(15,8)$; "a causa de las tronadas, y lluvias extraordinarias" $(33,3)$, "negros, zambos y mulatos" $(29,6)$. 
tomate ( $7 \mathrm{a}, 6)$, y a los quechuismos chucho 'fiebre intermitente', 'escalofrío' (1a, 6), chacra $(36,5 ; 45,4)$, chasque $(21,5)$, papa $(2 \mathrm{a}, 5)$. Aunque se duda sobre la filiación taína de tabaco (Ex. 1, 9; 16, 1 y 2), su universalidad resulta obvia, con referencias continuadas a sus diferentes variedades regionales, aquí defendida en el contexto "tabaco de Bracamoros, que hace las delicias de los aficionados de Lima y de sus costas" $(16,2)$. Segura adscripción regionalista presentan los términos quechuas combo 'martillo, mazo' (17, 1), considerado americanismo general, pique 'pulga' (1a, 6), de uso peruano ante el taíno nigua, putei 'planta solanácea que produce un tipo de baya anaranjada', registrada en la forma puten $(16,3)$, que Malaret registra en el Perú, el aztequismo pulque $(44,5)$, más usado en México y Ecuador, según el $D R A E$, y la mapucha güincha 'cinta de tela', con la variante del contexto hueincha (2a, 5), que Neves (1975), s. v. huincha, adscribe a Chile y Argentina, y que Morínigo (1985), s. v. güincha, restringe a Chile, aunque la Academia, s. v. vincha, estima de etimología quechua, con uso en Honduras y América Meridional. Se discute el origen tupí-guaraní de la voz gaucho $(9 \mathrm{a}, 1)$, pero no su conocimiento y su empleo en la población rioplatense.

El vocabulario de origen extranjero muestra, como en el caso del léxico ilustrado, la impronta de las lenguas francesa e inglesa. Así, a los términos impregnados de ideología ilustrada francesa o de campos jergales vistos en el apartado anterior (por ejemplo, jacobinismo, convoyar), están presentes préstamos galicistas como ambigú $(22,7)$, que el CORDE documenta en mitad del s. XVIII, complot $(10,8)$, estofa 'tela de colores' $(23,2)$, pantalón $(8 \mathrm{a}, 8)$, la Academia no lo recoge hasta 1843 , según el $D C E C H$, aunque se documenta en 1800, y Álvarez de Miranda (2004: 1053) lo refiera al grupo de voces francesas que penetran en nuestra lengua en el s. XVIII, rada 'bahía, ensenada', $(13,9)$, que registra Autoridades, según el $D C E C H$, vivaque (10a, 1), y los calcos semánticos electrizar 'enardecer' $(37,3)$, ya en Terreros, y globo 'planeta' (40,3), ya criticados por Capmany, según el DCECH (Frago, 2007: 171). Igualmente, tenemos los anglicismos léxicos club (11a, 3), lord $(2,7)$, milor $(30,2-3)$, que la Academia mantiene con su forma original milord, ron "destilacion de un aguardiente, que los Ingleses llaman Rum", "el Ron" (24, 2), ambas formas del s. XVIII (Álvarez de Miranda, 2004: 1054), los calcos semánticos doméstico 'nacional' $(10,5)$, sentido que reprueba el $D P D$, especialmente en su empleo de vuelos doméstico, parlamento $(12,6)$. Se hace eco también de los xenismos bill 'proyecto' $(11,3)$, que se recoge en el s. XVIII (Álvarez de Miranda, 2004: 1054), jurí 'miembro del jurado', pannel 'lista del jurado', sheriff, verdict (12a, 3), etc. 
La innovación americana en el proceso derivativo está representada en las adjetivaciones dañoso $(2,1 ; 2,4 ; 31,3 ; 37,6)$, "tierras humedas y charcosas" $(4,5 ; 4,7)$, desdoroso $(8 \mathrm{a}, 5)$, extremoso $(16,8)$, gravoso $(37$, $5)$; o los sustantivos bodegoneros 'tendero' $(2 \mathrm{a}, 5)$, esclavatura $(11,3 ; 12$, 1), que el CORDE documenta en el chileno Vicente Pérez Rosales (1882); peninsulano $(38,4)$; plantador $(11,3)$, en Argentina 'colono o dueño de una plantación', según el DRAE; los deverbales avanzada $(44,5)$, denuncio "compruebe el denuncio" $(26,5)$, americanismo general para el DRAE; desgreño $(12,6 ; 41,1)$, hoy en Argentina, Colombia, Chile 'desorden'; llamado ("ocurra al llamado de su alcalde" 8, 6), percibo "percibo del liquido" (26, 5), salteo ("se comenten salteos, robos" 8a, 1). Ya en el nivel morfológico, cabe recordar el empleo de -ito con sentido más cualitativo que cuantitativo, tan del gusto del lenguaje popular americano: cosita (41, 2), cartita (5a, 7), pueblecito (9a, 1), exemplito $(2 \mathrm{a}, 5)$.

\section{MUESTRA DE RASGOS GRAMATICALES DIALECTALES}

El recurso continuado a construcciones habidas en el español de otros tiempos ofrece una impronta tradicional, más acorde con los estilos escriturarios formales, pero en muchos casos reveladores de tendencias asimismo dialectales y, por tanto, de discutible carácter arcaico. La expresión de origen luso que pasó a nuestra lengua como echar menos y echar de menos se mantiene en la forma primera en el español peninsular hasta principios del siglo XIX, pero perdura en Colombia, noroeste argentino, Santo Domingo y otra partes de América, como comenta el DCECH. Aquí se ofrecen muestras con mayor abundancia de la primitiva: "se hechaba menos un Periódico" (Pr., 3), "echan ménos el antiguo despotismo" $(18,4)$, "Echais menos la soberbia" $(26,6)$, "echamos menos la execucion" $(42,5)$, aunque también aparece la prepositiva,"los casos en que se echa de menos una sociedad filantrópica" $(16,2)$. Caso contrario sucede con la expresión galicista tener lugar, criticada y no admitida por la Academia hasta 1852 $(D C E C H)$, "deba tener lugar en la Marina" $(2,6)$. 
Igualmente, la omisión del $\operatorname{artículo~}^{13}$ revela hábitos discursivos de épocas pasadas que se manifiestan en muchos contextos de este periódico: "congratulamos à la patria en persona de V. E." $(25,5)$, "daremos à luz" (2, 2) "sacarà à luz" $(10,5)$, "salgan à luz" $(3,5)$, sobre todo en las referencias temporales, o delante del que relativo (Girón Alconchel 2004: 881-882), que tienen una adscripción medieval y un uso abundante en el español americano (Kany 1976: 39, 40-41, 44 y 76; Frago 2007: 174): "todos tiempos" (1, 4; 12 , $7)$, "en todos tiempos aquellos" $(2,6)$, "los días en que se abran las fuentes" (Pr., 3), "una epoca en que la municipalidad concibe" $(41,1)^{14}$.

La ausencia de la preposición de en la completiva sustantiva o adjetiva tiene vigencia aún y persiste, por tanto, el queísmo (Girón Alconchel 2004: 879, Company 2009: 2a, I, 52) en la sintaxis más allá del s. XVII: "Ni se puede dudar la bizarra disposicion" $(15,8)$, "pribarles salir de su casa", "se pribo que pudiera salir" $(21,2)$, "Esté pues V. E. persuadido que esta plaza" $(21,3 ; 27,2)$, "Nos lisonjeamos, que esa Junta" (Ext. 2, 2), "no dudo que" $(21,5)$, "Estoy seguro, que no existe" $(44,7)$, "Hay noticias muy privadas que nuestras tropas" $(37,2)$, "todos gozaremos la influencia saludable del clima de la paz" $(5,8)$, "estamos convencidos que no podemos" $(7,5)$, "se me informó que varias divisiones Inglesas" $(9,2)$. Esta falta prepositiva en estructuras regidas de las que habla Kany para algunas regiones americanas (1976: 408 y ss.) también aparece: "se ha apropiado los conocimientos de

13 Un estudio extenso sobre esta cuestión puede verse en Lapesa (2000: 388-401).

14 Citas: "avanzar segunda véz contra Badajòz" $(9,2 ; 9,4)$ "triunfó segunda vèz" $(10$, $9)$, "en todas ocasiones há motivado la destruccion" $(5,1)$, "una tiranía de que quizà no hay exemplo" $(1,6)$, "de que no es pequeña prueba" $(22,6)$, "la crueldad con que habian sido tratados" $(1,7)$, "los quesos, de que hacen un gran consumo los Holandeses" $(2,5)$, "guerras [...] en que se destruyen" $(3,5)$, "utiles de que habla este escrito" $(4,2)$, "occeano vasto, é invisible en que nadan moléculas" $(4,6)$, "el sudor de Inglaterra, con que compraba la sangre" $(5,1)$, "esta es la razon por que no se alcanza", "pesos con que la Amèrica ha socorrido à la madre patria" $(5,3)$, "distinguidos elementos de ciencia con que construir" $(5,10)$, "el buen orden de que pende" $(7,1)$, "opresiones, y privaciones, en que la fatal ley de la conquista há indiscriminadamente emvuelto los descubridores, conquistadores, y establecedores de estos payses" $(7,3)$, "voluntad general, sobre que no obra el capricho personal" $(8,3)$, "el abandono en que estan las minas" $(14,4)$, "este es el principio por que los caudillos $[\ldots]$ se consideren constituidos por la misma divinidad" $(14,4)$, "el poder de que estan revestidos" $(14,4)$, "la nada de que salieron" $(30,4)$, "la causa porque se hayan desechado" $(15,3)$, "es igualmente la causa por que los vasallos de los gobiernos absolutos viven en una perfecta ignorancia" (31, 2), “accion magnánima de que nos sea capaz" $(24,4)$, “cabezas mal unidas" (pág. 16), "los medios de que se puede hacer uso" (1a, 1), "las causas de que proceden" (4a, 6), "llegaron los dias de que te se permita establecerlas" $(3,3)$, "Desde el momento, que los ultimos funcionarios tomamos las riendas" $(21,4)$, "el modo con que quiere que se eduquen sus hijos" $(11,2)$, "las nociones de que por falta de estudio del derecho publico carece" $(18,5)$. 
todos los siglos" (3a, 6), "delante quienes evolucionó por largo tiempo un gran cuerpo de Tropa" $(1,2)$. Se registra la persistencia de la preposición de en construcción agente o causal: "animada del movimiento se inflama" (4a, $6)$, "desconocidas de los gobiernos" $(30,1)$, "conducidos de las pasiones mesquinas" $(8,2)$, "están atacados de ella" $(10,9)$. Igualmente tradicional, aunque con uso dialectal americano, resultan los trueques prepositivos como $a$ por en, "se erige á nombre de la Patria" (2a, 3), pero sobre todo en verbos de movimiento (Kany 1976: 397), "sean admitidas en lo subcesivo à los colegios" $(2,6)$, "se refugió à las montañas" $(11,5)$; en o $a$ en lugar de por, en locuciones temporales, evidencia el peso tradicional, y hoy popular, no solo en la Península sino también en amplias zonas americanas ${ }^{15}$, "à la noche iluminación" $(1,2)$, "en la noche hubo iluminacion" $(36,7)$. Abunda el uso de la preposición $a$ para construcciones finales, muy común desde antiguo con verbos de movimiento, aunque Kany (1976: 440) lo hace extensivo, sin restricción semántica verbal, a la sierra ecuatoriana y en la de Perú, "se prepara à sostenerse" $(1,5)$, "dia feliz á Chile" $(21,4)$, "se presenten á su propio bien" (1a, 3), "Es muy dañoso a los pueblos" (2, 1; 10, 4), "mas ignominioso á nosotros mismos " $(7,6)$, "necesario á la conservacion de la tranquilidad" $(14,4)$, etc.

El empleo de la preposición $a$ en el objeto directo de persona ${ }^{16}$ alterna con la construcción asindética: "tomar à Astorga" $(9,4)$, "educar y alimentar la prole" $(9,7)$, "mató inmenso numero de Cartaginenses" $(4,6)$, "gobernar unos seres debiles" $(10,1)$, "se eduquen los jovenes" $(10,1)$, "hacer ilustres é inmortales muchos hombres" (32,7), "renunció mil veces la corona" (37, 5), "salvar la gente" (1a, 7), "sorprehendió el pueblo" $(10,6)$, etc.

El apartado pronominal confirma determinadas marcas dialectales, algunas de clara impronta meridional, como el uso etimológico de los clíticos, y otras de tradición específica americana, como el fenómeno voseante. No obstante, el leísmo, y no solo con persona, que, según Kany (1976: 133139), ya alternaba en la escritura y, ocasionalmente, en el habla culta ${ }^{17}$, está presente en el periódico, "Al enemigo le he mandado perseguir" $(37,1)$,

15 En América son frecuentes locuciones como a las cansadas por a las tantas, al grito por al momento, es decir, tienen un empleo muy popular, especialmente en el Río de la Plata (Kany 1976: 333).

16 Véase, al respecto, los usos y la extensión de la construcción prepositiva en Lapesa (2000: 93-99); Quesada Pacheco (2002: 113-114) estima que la estructura asindética en el objeto directo de persona, en el dativo personal y en las perífrasis verbales, se da entre hablantes de menor nivel de escolarización de toda América.

17 Según Abadía de Quant (2004: 139), el leísmo aparece en todos los isolectos del español del nordeste argentino. 
"le hagan figurar entre naciones" $(25,6)$, "le apiedraban à los soldados" $(46,2)$, con el pronombre invariable, además de algunos casos de loísmo y de laísmo, que resultan más extraños en el lenguaje escrito periodístico: "qualquiera puede hablarlos [a los hombres]" $(36,3)$, "no los ha permitido salida alguna" $(43,3)$, "seguirla prestando toda clase de auxilios" $(21,6)$, "procurarlas [a las prostitutas] un asilo para su curacion" $(6 a, 5)^{18}$. El posesivo postpuesto también se detecta, "en contra mía" $(17,3)$, ya reprobado en tierras americanas por los gramáticos, según comenta Kany (1976: 66), pero que tiene un empleo general en estas tierras y en las meridionales de la Península. El tratamiento voseante documentado obedece al estilo discursivo del texto reproducido: "Vos, en cuyas manos están los destinos de tantos hombres, no sentis" $(28,3)$, "Vos y yo, hombres del Estado" $(40,3)$, que reproducen un texto legal antiguo, "valemos tanto como vos" $(9 \mathrm{a}, 6)$, "se volvieron hacia vos mi corazon y mis ojos" (11a, 1).

En el terreno adverbial, se registran contextos que recuerdan la época clásica y que gozan de amplia repercusión en las hablas meridionales peninsulares. De esta manera, bien aparece como intensificador, "hombre bien trabajador" $(16,2)$, "América ha sido bien insulsa é infeliz" $(29,1)$, "un asunto bien pobre" $(29,7)$, y entra en la locución concesiva bien que, propia, según la Academia, de escritos elevados y menos frecuente en textos americanos $(N G: 47,16 n)$, "bien que nada hay nueva" $(46,7)$; a registros más populares que dialectales se deben muy y como, en construcciones adjetivas (Hanssen 1966: 268), "un paso mui de tortuga" $(41,2)$, "en otros como a los 19 años" $(3,7)$, "como de 1000 paysanos" $(9,4)$; el uso alternante con el comparativo como de cuando (Hanssen 1966: 280), "una hora cuando menos" (Ex. 1, 2); la construcción mientras más en sustitución de la locución cuanto más, de mayor vigencia en América (Kany 1976: 74-75), "mas dificil mientras mas nos aumentemos" (17, 7), "mientras mas tiempo duren" $(25,8)$. El factor preferente explica acá $(20,3)$, allá $(5 \mathrm{a}, 1)$, tan extendido en la zona rioplatense y zonas andinas (Kany 1976: 319), afuera "á afuera" (1a, 7), "de afuera" $(39,5)$, generalizado en América (Kany 1976: 325); y el carácter más conservador justifica la permanencia de

18 Citas: "le queman en parrillas" $(17,5)$, "le pueda igualar", "defendiendole por el oriente los Andes" (3, 4), "avisarles" (Ex. 1, 2), "les ayuda" (1a, 1), "pidió que le relevasen" $(5,7)$, "reconocerle solo condicionalmente" $(7,5)$, "le sirva" $(12,1)$, "actual regencia, sustituyèndole un nuevo gobierno" $(15,4)$, "le trajo" $(41,2)$, "les han obedecido" (7a, 5), "le prive" $(5 \mathrm{a}, 6)$, "le atacó" (9a, 7), "les acometieron" (37, 2), "gente que les acompañò" $(21,6)$, "le vimos" $(28,6)$, "pueda sobrevivirle" $(30,1)$, "les gobierne" $(34,1)$, "le rodean", "le oprime" $(33,6)$, "le hicieron señora del mundo" $(24,4)$, "le detenga" (1a, 5), "que les compelamos à ello" (10, 5), "[a las plantitas] se les trasplanta" $(16,2)$, "le persuadió" 32, 5), etc. 
luego 'de repente, inmediatamente' aún vigente en América, "será empleado en el exercito luego" $(2 \mathrm{a}, 8)$, "nos uniremos muy luego" $(15,8)$, "reiterara muy luego" (21, 5), el latinismo inter, "inter exista $(20,3)$, "interin se daba parte" (Ext. 2, 1), conservado como mientras en zonas americanas (Kany 1976: 75), la gradación restrictiva menos que, "no pueden menos que" (21, $4)$, "no hemos podido menos, que resentirnos" $(21,5)$, "no puede menos que confesar" $(21,6)$, y el empleo variado de no más, aquí como refuerzo con el significado de 'precisamente', tan extendido en Hispanoamérica, aunque con la excepción de las Antillas (Kany 1976:167-172), "uno de los soldados no mas fuera de otros tomó hasta quatrocientas onzas" (36, 7), etc. La variación inherente al discurso se constata en el empleo de presto, de amparo valdesiano, "pasa presto" $(37,4)$, pero también de pronto, habitual a finales del s. XVIII ( $D C E C H)$, con el significado adjetival más antiguo, "estàn prontos" $(6,3 ; 38,1)$, "está pronta para envarcarse" $(8,4)$, "prontos á marchar á la defensa de nuestros derechos" $(8,5)$, "Si hubiéramos tenido prontos quince mil hombres" $(9,3)$, "aprobacion pronta ó tarda" $(30,2)$. Idéntico sabor tradicional se produce en la adverbialización de infinito, "se ilustraría infinito la nacion" $(9,6)$, en el refuerzo identificativo propio, "A el propio Lima" $(36,7)$, o en de balde $(32,4)$, "De valde se cansan los tiranos" $(36,6)$, con el sentido 'sin motivo'.

La categoría verbal nos revela del mismo modo las variantes del sistema con recursos de sabor tradicional y hábitos más caracterizadores desde la perspectiva diatópica ${ }^{19}$. La tendencia más antigua se observa en los contextos: "La solución de este problema es sobre nuestros alcanzes" $(2,3)$, "es entre ellos una preocupacion antiquisima que ningun hombre de alguna comodidad muere naturalmente" $(3,5)$, "Tiempo ha que" $(18,4)$, "nos han muerto 25.000 Hombres" $(3,5)$, "habiendole una bala muerto el caballo" $(10,7)$, con extensión en otros participios cultos, "se han electo Diputados" (4a, 8), o la presencia abundante del futuro de subjuntivo en la frase "Sea lo que fuere" $(16,4 ; 33,2 ; 41,2$ con múltiples citas análogas en $25,9 ; 30,2 ; 33,6 ; 5,4)$, "suceda lo que sucediere" $(17,2)$, tan extendida en documentos administrativos y legales que llega hasta nuestros días en el español de ambas orillas, y en otros contextos comunes que nos previene del comentario tan generalizado de su falta de productividad, especialmente

19 Discutible parece la diferencia dialectal americana en el supuesto uso del pretérito perfecto simple frente al compuesto, sobre todo en las Antillas, aunque aquí, en zona chilena, se detecta cierto sentido enfático o de realce en el empleo de la forma compuesta tras el adverbio ayer, "Ayer ha salido una diputación con pliegos para Montivedeo" $(33,4)$, "Ayer han entrado en el puerto Talcahuano tres fragatas" (10a, 4). 
en textos americanistas: "si el enemigo avanzare, reunirá el Lor sus fuerzas" $(10,8)$, “en los lugares que eligeren" $(12,6)$, "se presentaren á nuestros ojos" $(18,5)$, “á los que nacieren" $(18,10)$, "cuesten lo que costaren" $(20,3)$, "si lo hallare" $(40,6)$, "si hubiere de reducirse [...] saldrían" (3a, $7)$, en confrontación con el imperfecto más proclive en las condicionales, etc. Igualmente, se rastrea la construcción tradicional en + gerundio, hoy para sucesos del pasado (Hanssen 1966: 261) y ocasionalmente en países americanos ( $N G$ 27, 4j): "en siendo malos los Gubernantes, no habremos hecho otra cosa que" $(39,4)$, "en prosiguiendo con esta política vendràn sobre nosotros" $(10,5)$, "en diciendo español todas las naciones tiemblan" $(27,2)$, "en señoreandose [...] intentaría hacer", "en teniendo suficiente fuerza" $(35,2)$, "no desertaran en sabiendo que" (4a, 3), "en apareciendo" (Suplemento 1, 1), etc. Se constata un mayor uso de -ra que de -ría, como valor de irrealidad, y se observa la alternancia con su alomorfo -se en las condicionales ${ }^{20}$ : "El fuera infelíz en este nuebo estado, si viviese sin reglas" $(1,3)$, "no podemos afirmar que lo fuese alguna vèz" $(3,5)$, "el pueblo viviera siempre en inquietud", "habriamos perdido la memoria con la voz, si fuera mas facil olvidar, que guardar silencio" $(30,2)^{21}$.

En el nivel oracional, la ausencia del nexo que en oraciones completivas resulta muy común, incluso con verbos conjugados en indicativo, y se confirma que su extensión al s. XIX no solo se produce en textos jurídicos y literarios (Girón Alconchel 2004: 879-880), sino que tiene un uso más general en el dialecto americano: "parecen confían en que el siguiente golpe ha de terminar esta guerra" (Ex. 1, 6), "Algún tiempo hace savemos [...] que el gobierno Ingles había pedido à las Cortes se abriese à sus subditos" $(10,4)$, "desesperaba, fuesen todos inutiles" $(36,6)$, "no podemos sino concebir sea creible" $(10,4)$, "temia se tomase" $(20,3)$, "no parece posible vuelva á organizarse" $(24,6)$, "pedian se le cerrasen los puertos" $(41,6)$, "se ordena y manda se celebren" $(6 \mathrm{a}, 7)$, "ordena y manda se publiquen"

20 No aparecen contextos en los que estas formas verbales estén siendo sustituidas por las del presente de subjuntivo, como se viene aduciendo para la variedad americana, quizás porque se insiste en la preferencia, en estos casos, del registro hablado y no del escrito.

21 Citas: "¡quán triste y horroso fuera el aspecto del mundo, si el duro egoismo llegase à ocupar todos los corazones! [...] el estado se perdiera, y todos se perdieran con él" $(2,4)$, "Los hombres, decia Platon, fueran felices, si los filosofos imperase, ó fuesen filosofos los emperadores" $(13,2)$, "debiera concluirse, que el reino de Chile gozase de una poblacion numerosisima", "en la guerra sufriera todos los estragos" $(6,8)$, "Conviniera por tanto, que se les opusiese una fuerza" $(25,7)$, "no fuese que, socolor de religion, se abusase" $(11,4)$, "si alguna vez les causasemos el menor daño [...] todos nos cubririamos de luto" $(21,4)$, "todo se confundiera, si todos ondasen" $(31,2)$, "mui bueno fuera que se imaginase un arbitrio" $(41$, 1), “yo deseara que [...] se empeñase el talento humano á manifestar lo mejor" (1a, 2), etc. 
$(7 \mathrm{a}, 3)$, "no se concibe sea adecuada para executar alguna cosa seria" (5, $7)$, "he mandado se completen grandes obras" $(5,7)$, "dispuso se celebrase" $(40,7)$, "que fuera oportuno se informase el Cabildo" $(41,2)$, "ni presume hayan pasado" (10a, 5), etc.

La expresión de la causa se plasma en casos con fórmula adverbial locativa, que recuerdan modelos medievales (Hanssen 1966: 276), con referencias anafórica o catafórica de la causa o consecuencia, según el modo verbal ${ }^{22}$ : "De aqui es que la ilustracion es mas general" $(13,3)$, "De aqui es que no se encuentra algún pueblo, que no haya sufrido la tiranía" $(1,3)$, "De aqui es que en hacerse amar ha consistido siempre lo sublime de la politica" $(26,6)$, "De aqui es que las actuales circunstancias de la America exigen genios criadores" 30,4$)$, "De aqui es, que en las grandes poblaciones nacen las epidemias" $(4,4)$, "de aqui és, que en las crisis peligrosas de los estados fué el ultimo recurso" $(10,3)$, "de aqui es que por medio de exercicios $[\ldots]$ estos espectáculos marciales sean tan gratos" $(6,7)$. A registro más popular se debe la preferencia por la locución condicional "que de no, estubieran en la calle muchas familias" $(31,6)$, frecuente en numerosas regiones americanas Kany (1976: 351), o la negativa con matiz consecutivo "tal que no se note" $(23,8)$.

Tendencia arcaizante aparece en construcciones absolutas con relativo (Hanssen 1966: 258-259), "llegada que fue la luz" (21, 2), y en el empleo de ella como sujeto en la frase copulativa tan común en el español hasta el s. XIX (Kany 1976: 165), "Ella es cierto que abunda en volcanes" (4a, 7). La preferencia culta por la construcción pasiva refleja ${ }^{23}$ y el uso más popular de la estructura impersonal ofrecen índices de frecuencia distintos según el uso peninsular y americano, con mayor presencia de las pasivas en el español general y de impersonales en las variantes dialectales (Bosque y Demonte 1999: 1631-1722). Las citas confirman las estructuras reflejas concertadas, "se apresan bandidos" $(9,2)$, "se nombran para su execucion los xefes de los cuerpos de granaderos" (Ex. 1, 2), "se apresaron un teniente coronel, y cincuentas hombres" $(10,6)$, "se han descubierto dos personas" $(11,1)$, "las fuerzas de los insurgentes se han aumentado" $(24,7)$, pero también las impersonales concertadas, tan extendidas en los dialectos meridionales

22 Elvira (2004: 460) ejemplifica construcciones muy comunes en el terreno de la expresión causal, en las que la subordinada causal aparece enunciada por un sintagma preposicional con pronombre demostrativo o con relativo: por esto es, el que.

23 Las encuestas del Proyecto Coordinado para el Estudio de la Norma Lingüística Culta, de la $A L F A L$, registran para el español bonaerense una mayor presencia de estructuras pasivas reflejas que de impersonales (Fontanella de Weinberg 1992: 154). 
peninsulares como en América, "hubieron hombres" (45, 3), "hubieron 120 , heridos" $(9,3)$, "han habido enemigos" $(33,1)$, "Habian centenares de fanaticos, habian credulos, habian egositas" (6a, 3), "habian muy pocos hombres" (9a, 1), etc. Contraste dialectal se observa en construcciones reflexivas, de mayor frecuencia en las hablas americanas (Kany 1976: 227): "Tres marineros europeos fugaron por Montevideo" (1a, 7), "se desertaron mas de sesenta hombres" (1a, 7), "lanchón, que fugo" (3a, 2).

\section{EPÍLOGO}

Los resultados del análisis lingüístico de la Aurora de Chile permiten constatar que su director y los redactores o colaboradores emplean un vocabulario representativo de los hechos históricos que manifiesta, caracterizado por los términos propios de esta etapa revolucionaria, que se han adaptado a la nueva realidad del continente americano. La incorporación de los neologismos, anglicismos y galicismos, por razones históricas obvias, especialmente por la relación con los principios republicanos que definen tanto el sistema político francés como el más cercano de Estados Unidos, repiten los usos peninsulares con escasas muestras de americanismos exclusivos. La cala léxica en el terreno del vocabulario iluminista empleado en el periódico ofrece datos interesantes para la historia de voces patrimoniales, ya documentadas en el español general, pero ahora con mayor vigencia y provistas de las nuevas acuñaciones ideológicas ilustradas, y confirma el aumento del bagaje léxico que las ciencias y sus descubrimientos procuran a nuestra lengua. La proporción de términos del español común es indiscutible, aunque se admitan préstamos léxicos y calcos semánticos de las otras lenguas implicadas en los cambios sociales, culturales y políticos de esta época de la independencia. Por otro lado, desde la perspectiva dialectal, la criollización léxica es manifiesta y se detectan innovaciones definitorias de la aclimatación de nuestra lengua en América y, más concretamente, en la nueva república de Chile, como también del uso de indigenismos de clara extensión panamericana y general en la lengua española. 


\section{REFERENCIAS BIBLIOGRÁFICAS}

Abadía de Quant, I. 2004. El español del Nordeste, en María Beatriz Fontanella de Weinberg (coord.), El español de la Argentina y sus variedades regionales. Bahía Blanca: Proyecto Cultural Weinberg/Fontanella, pp. 121-159.

Alvar, Manuel. 1987. Léxico del mestizaje en Hispanoamérica. Madrid: Cultura Hispánica e Instituto de Cooperación Iberoamericana.

Álvarez de Miranda, Pedro. 1985. Proyectos y proyectistas en el siglo XVIII español. Boletín de la Real Academia Española LXV, pp. 409-429.

1992. Palabras e ideas: el léxico de la Ilustración temprana en España (16801760). Anejo del Boletín de la Real Academia Española, LI.

2004. El léxico español, desde el siglo XVIII hasta hoy. En Rafael Cano Aguilar (coord.). Historia de la lengua española. Barcelona: Ariel, pp. 1037-1064.

Aurora DE ChILE (1812-1813). 2003, ed. facsimilar. Proyecto de Newtenberg Publicaciones Digitales [en línea]. Disponible en $<\mathrm{http}: / / w w w$. auroradechile.cl $>$ [consulta].

Bosque, Ignacio y Violeta Demonte. 1999. Gramática descriptiva de la lengua española. 3 vols. Madrid: Espasa Calpe.

Chuchuy, Claudio (coord.) 2000. Diccionario del español de Argentina. Madrid: Gredos. $(E A)$.

Company Company, Concepción (dir.). 2009. Sintaxis histórica de la lengua española. Primera parte: I y II. Segunda parte: I y II. México D. F.: UNAM y Fondo de Cultura Económica.

Corominas, Joan y José A. Pascual. 1980-1991. Diccionario crítico etimológico castellano e hispánico. Madrid: Gredos. (DCECH).

Elvira, Javier. 2004. Los caracteres de la lengua: gramática de los paradigmas y de la construcción sintáctica del discurso. En Rafael Cano Aguilar (coord.). Historia de la lengua española. Barcelona: Ariel, pp. 449-472.

Fontanella de Weinberg, María Beatriz. 1992. El español de América. Madrid: Mapfre.

Frago Gracia, Juan Antonio. 1999. Historia del español de América. Madrid: Gredos.

2007. Tradición e innovación en el español americano. Romance Philology, 61, pp. 148-191.

Franco Figueroa, Mariano. 2007. Usos discursivos y aculturación en la Descripción de Fray Reginaldo de Lizárraga y en la Crónica de Guamán Poma. En I. Delgado Cobos y A. Puigvert Ocal (eds.). Ex admiratione et amicitia. Homenaje a Ramón Santiago. Tomo I. Madrid: Ediciones del Orto, pp. 465-490.

García Godoy, María Teresa. 1998. Las Cortes de Cádiz y América. El primer vocabulario liberal español y mejicano (1810-1814). Sevilla: Diputación de Sevilla. 
Gardella, Graciela De. 1969. Contribución al estudio del lenguaje de los hombres de Mayo. Thesaurus, Boletín del Instituto Caro y Cuervo, XXIV, pp. 178-227.

Girón Alconchel, José Luis. 2004. Cambios gramaticales en los Siglos de Oro. En Rafael Cano Aguilar (coord.). Historia de la lengua española. Barcelona: Ariel, pp. 859-893.

Granda, G. DE. 1997. Replanteamiento de un tema controvertido. Génesis y retención del doble posesivo en el español andino. Revista de Filología Española, 77, 1-2, pp. 139-147.

Guitarte, Guillermo. 1980. Para una periodización de la historia del español de América. En Juan M. Lope Blanch (ed.), Perspectivas de la investigación lingüistica hispanoamericana. Memoria. México: Centro de Lingüística Hispánica, UNAM, pp. 119-137.

Hanssen, Federico. 1913. Gramática histórica de la lengua castellana. Edición facsímil. Paris: Ediciones Hispanoamericanas, 1966.

Hildebrandt, Marta. 1961. La lengua de Bolivar. I. Léxico. Caracas: Universidad Central de Venezuela.

Kany, Charles. 1976. Sintaxis hispanoamericana. Madrid: Gredos.

LAPESA, RAFAEL. 1966-1967. Ideas y palabras: del vocabulario de la ilustración al de los primeros liberales. Asclepio, Archivo Iberoamericano de Historia de la Medicina, XVIIIXIX. Madrid, pp. 189-218. - 2000. Estudios de morfosintaxis histórica del español. Madrid: Gredos.

Marty Caballero, D. E. 1871. Diccionario de la lengua castellana. Tomo I y II. Madrid: Manuel Rodríguez, Editor.

Matus, Alfredo, Soledad Dargham y José Luis Samaniego. 1992. Notas para una historia del español en Chile. En César Hernández Alonso (coord.). Historia y presente del español de América. Valladolid: Junta de Castilla y León, pp. 543-564.

Morínigo, Marcos. 1985. Diccionario de americanismos. Barcelona: Muchnik Editores.

Neves, Alfredo. 1975. Diccionario de americanismos. Buenos Aires: Editorial Sopena.

Quesada Pacheco, Miguel Ángel. 2002. El español de América. Cartago: Editorial Tecnológica.

Real Academia Española. Banco de datos (CORDE) [en línea]. Corpus diacrónico del español [en línea]. Disponible en $<\mathrm{http}: / / \mathrm{www} \cdot$ rae.es $>$ [consulta]. Academia).

Real Academia Española y Asociación de Academias de la Lengua Española. 2005. Diccionario panhispánico de dudas. Madrid: Editorial Santillana.

2009. Nueva gramática de la lengua española. I. Morfología. Sintaxis; II. Sintaxis. Madrid: Espasa Libros. (NG).

Terreros y Pando, Esteban. 1786-1793. Diccionario castellano de las voces de ciencias y artes, I-II-III-IV, ed. facsímil. Madrid: Arco/Libros, 1987.

Thiulen, L. I. 1813. Nuevo vocabulario filosófico-democrático, indispensable para los que deseen entender la nueva lengua revolucionaria. Escrito en italiano, y traducido al español. Sevilla. Edición facsimilar, de la reimpresión hecha en Barcelona, de Editorial Maxtor. Valladolid. 2006. (VFD).

Vallejos Llobet, Patricia. 1987. El léxico iluminista en el primer periódico rioplatense. Anuario de Lingüística Hispánica, III, pp. 203-221.

Villar, Manuel del. 1982. Aurora de Chile. Primera edición facsimilar. Santiago de Chile [en línea]. Disponible en http://www.auroradechile.cl/newtenberg/681/article-2358.html [consulta]. 